\title{
Comparative somatic cell score and milking characteristics of Holstein-Friesian, Jersey and Jersey $\times$ Holstein-Friesian cows at pasture
}

\section{R. Prendiville ${ }^{1,2}$, K.M. Pierce ${ }^{2}$, F. Buckley ${ }^{1}$}

${ }^{1}$ Teagasc, Moorepark, Dairy Production research Centre, Fermoy, Co. Cork, Ireland

${ }^{2}$ School of Agriculture, Food Science and Veterinary Medicine, UCD, Belfield, Dublin 4, Ireland

Email: robert.prendiville@teagasc.ie

Introduction Inferior udder health can be a source of economic loss to both producer and processor (Walsh et al., 2007). In Ireland, some processors, as an incentive to improve milk quality, have introduced bonus schemes for herds achieving bulk somatic cell count (SCC) of 200,000 cells/ml or less. Milking characteristics are important functional traits of dairy cows which influence labour cost (Boettcher et al., 1998), rate of involuntary culling (Berry et al., 2005) and udder health (Rupp and Biochard, 1999). The aim of this study, carried out at the Ballydague research farm, was to investigate the somatic cell score (SCS) and milking characteristics of Holstein-Friesian (HF), Jersey $(\mathrm{J})$ and Jersey $\times$ Holstein-Friesian $\left(\mathrm{F}_{1}\right)$ cows in seasonal pasture based systems.

Material and methods A total of 329 lactations across three years (2006-2008) were available, $112 \mathrm{HF}, 106 \mathrm{~J}$ and $111 \mathrm{~F}_{1}$ from 162 cows; $65 \mathrm{HF}, 48 \mathrm{~J}$ and $49 \mathrm{~F}_{1}$. Cows grazed as a single herd for the first two years of the study and in 3 separate treatment groups in year 3. In mid-April of year 1, cows were randomised across two grass based feeding systems; low concentrate $(658 \mathrm{~kg} \mathrm{DM} / \mathrm{cow})$ and high concentrate $(1072 \mathrm{~kg} \mathrm{DM} / \mathrm{cow})$. In year 2 , all cows were managed in a similar fashion to the low concentrate group in year 1 . In year 2, concentrate supplementation averaged $240 \mathrm{~kg} \mathrm{DM} / \mathrm{cow}$. In year 3 , cows were randomly assigned within breed to a $3 \times 3$ factorial experiment comparing the $\mathrm{HF}, \mathrm{J}$ and $\mathrm{F}_{1}$ cows under three stocking rate systems with concentrate supplementation amounting to $352 \mathrm{~kg} \mathrm{DM} / \mathrm{cow}$. Mean lactation number was 1.74 lactations across the breed groups. Somatic cell count (SCC) was determined biweekly, from morning samples using a Bentley Somacount 300 (Bentley Instruments Inc., Chaska, MN). The natural logarithm of SCC was used to define SCS. A total of 8,048 test-day records were available for SCS analysis. Mean SCS records for cow within lactation were used to determine average SCS over lactation. Milk yield and milking characteristics were recorded daily throughout lactation providing a total of 13,446 test-day records. Average milk flow (AMF), peak milk flow (PMF) and milking duration (MD) were recorded daily using electronic milk meters. Average milk flow, PMF and MD were determined weekly and subsequently averaged within lactation. Data were analysed using the mixed procedure of SAS (Statistical Analysis System, version 9.1; SAS Institute Inc., Cary, NC, USA, 2003). The linear model included the fixed effects of breed group $\left(\mathrm{HF}, \mathrm{J}\right.$ and $\mathrm{F}_{1}$ ), parity, year and feeding treatment. Calving day of year and lactation length were fitted as continuous covariates. Cow was included as a repeated effect. Using the Akaike's information criterion, a compound symmetry structure for the residuals was determined as the most appropriate residual covariance structure for repeated measures over time within cows. Breed groups (HF vs. J) and the $\mathrm{F}_{1} v s$. the mid-parent mean, were compared using orthogonal contrast statements.

Results Milk yield was greater for the HF compared to the J, while SCS was similar for the two breeds (Table 1). Average milk flow was greater with the HF compared to the J. Peak milk flow tended to be higher with the HF. The $\mathrm{F}_{1}$ had a greater milk yield, AMF and PMF compared to the mean of the parent breeds. This corresponded to hybrid vigour estimates of $+1.0 \mathrm{~kg}(+5.8 \%),+0.10 \mathrm{~kg} / \mathrm{min}(+7.9 \%)$ and $+0.32 \mathrm{~kg} / \mathrm{min}(+10.3 \%)$ for milk yield, AMF and PMF, respectively. Milking duration was similar across the three breed groups.

Table 1 Effect of breed on milk yield, SCS and milking characteristics.

\begin{tabular}{|c|c|c|c|c|c|c|c|}
\hline & \multicolumn{3}{|c|}{ Breed group } & \multicolumn{2}{|c|}{ HF v J } & \multicolumn{2}{|c|}{$\mathrm{F}_{1} \mathrm{v} \cdot$ parent mean } \\
\hline & $\mathrm{HF}$ & $\mathrm{J}$ & $\mathrm{F}_{1}$ & S.E.M. & P-value & S.E.M. & P-value \\
\hline Milk yield $(\mathrm{kg} / \mathrm{d})$ & 18.0 & 14.2 & 17.1 & 0.29 & $<0.001$ & 0.26 & $<0.001$ \\
\hline Somatic cell score & 10.6 & 10.8 & 10.7 & 0.15 & NS & 0.13 & NS \\
\hline Average milk flow (kg/min) & 1.36 & 1.09 & 1.33 & 0.037 & $<0.001$ & 0.033 & $<0.01$ \\
\hline Peak milk flow (kg/min) & 2.93 & 2.65 & 3.11 & 0.154 & 0.067 & 0.140 & $<0.05$ \\
\hline Milking duration $(\log \mathrm{s} / \mathrm{d})$ & 6.64 & 6.62 & 6.62 & 0.024 & NS & 0.023 & NS \\
\hline
\end{tabular}

Conclusions Results from this study suggest no difference in SCS between the breed groups evaluated. While differences in milk flow were apparent between the breed groups, the findings indicate that $\mathrm{F}_{1}$ cows will, on average, exhibit similar $\mathrm{MD}$, ensuring consistency during the milking process in mixed breed/crossbred herds.

Acknowledgements Financial support from the Research Stimulus Fund (RSF-06-353) is gratefully acknowledged.

\section{References}

Berry D. P., Harris, B. L., Winkelman, A. M. and Montgomerie, W. 2005. Journal of Dairy Science 88: 2962-2974.

Boettcher P. J., Dekkers, J.C.M. and Kolstad, B. W. 1998. Journal of Dairy Science 81: 1157-1168.

Rupp R. and Boichard, D. 1999. Journal of Dairy Science 82: 2198-2204.

SAS User's Guide. 2006. Version 9.1: Statistics. SAS Inst., Cary NC, USA.

Walsh S., Buckley, F., Berry, D.P., Rath, M., Pierce, K., Byrne, N. and Dillon, P. 2007. Journal of Dairy Science 90, 57675779 . 